\title{
Study on the Fluidity and Strength Properties of High Performance Concrete Utilizing Crushed Sand
}

\author{
Sangjun Park* \\ (Received August 7, 2012, Accepted September 20, 2012, Published online October 17, 2012)
}

\begin{abstract}
Recently, it has been difficult to get natural sand for concrete due to an insufficient supply in Korea. Crushed sand was thought as a substitute and previous research has been focused on low fluidity and normal compressive strength (24-30 MPa). Study on high performance concrete using crushed sand is hardly found in Korea. In this study it was investigated that the effect of the crushed sand on fluidity and compressive strength properties of high performance concrete. Blending crushed sand (FM: 3.98) produced in Namyangju, Kyunggido and sea sand (FM: 2.80) produced in Asan bay in Chungnam. The final FMs of fine aggregate were $3.50,3.23$, and 3.08. W/B was set as 0.25 to get high performance. With the test results an analysis of relationship was performed using a statistical program. It was shown that strength property of concrete using crushed aggregate at the very early age or after specific time was mainly affected by strength development properties of binders instead of the crushed sand.
\end{abstract}

Keywords: high performance concrete, crushed sand, alterative aggregate, statistical analysis.

\section{Introduction}

In recent years, it has been taken a growing interested in the shortage of natural fine aggregate having good quality across the country, because of deficient natural sand supplies and increased construction demands. There is no significant difficulty to use the coarse aggregate by using not only the natural coarse aggregate but also the crushed aggregate. For the fine aggregate, however, it is very rare place where the good quality of that can be produced. Therefore it is more acceptable that most of all ready mixed concrete companies have used blended aggregates, mixed with natural and crushed sand (CS). However the use of the blended aggregates still has problems, which is only ordinary concrete can be applied due to the lower quality of it (Celik 1996). Although it is needed high quality concrete using improved crushed aggregate in many recent constructions it has not been studied.

Therefore in this study it was investigated that the practical use of high performance concrete with various blending ratios of both crushed aggregate and natural sea aggregate produced in Korea (Park 1998; Kim and Lee 1995; Chi et al. 2006). Based on the experimental results it was also evaluated the mutual correlation of mixing parameters using SPSS (statistical package for the social sciences) software.

Daewoo Institute of Construction Technology, Suwon City 440-210, Korea.

*Corresponding Author; E-mail: concrete@daewooenc.com Copyright ( $\odot$ The Author(s) 2012. This article is published with open access at Springerlink.com

\section{Experimental Design and Materials}

\subsection{Experimental Design}

Table 1 shows experimental details of this study. This experimental design is programmed to evaluate the application of high performance concrete using CS. The mixture proportion with water to binder ratio (W/B) of 0.25 only consisted of various blending ratios of CS versus sea sand (SS) such as $0,30,50,70$ and $100 \%$ respectively. In addition unit weight, shape index and shape modulus of fine aggregate were measured with blending ratios. Fly ash (FA) content is 0,10 and $20 \%$ cement replacement by mass. It was investigated the properties of fresh concrete, such as fluidity, air content and compressive strength and eventually evaluated mutual relation between mixture proportion factors using SPSS.

\subsection{Materials}

Type 1 ordinary Portland cement of H Company and FA of K Company were used. Details of the properties of the binders used are shown in Table 2.

Crushed aggregate was produced in Bibong-myeon, Hwaseong-si by using impact crusher. Coarse aggregate was also crushed aggregate. Their properties are shown in Table 3. Carboxylate based super plasticizer was used and its density and $\mathrm{pH}$ were respectively $1.045 \mathrm{~g} / \mathrm{cm}^{3}$ and 6.8 .

\subsection{Test Method}

To analyze the quality of blended fine aggregate, its bulk density and shape index were tested in accordance with KS F 2505 and KS F 2527. In test of shape index, sample of blended fine aggregate was passed through sieve of $2.5 \mathrm{~mm}$ by washing with water and residue aggregate on a sieve of $2.5 \mathrm{~mm}$ was fully dried. Dried aggregate was used in test of shape index. 
Table 1 Design of experiment.

\begin{tabular}{|c|c|c|c|c|c|}
\hline $\mathrm{W} / \mathrm{B}$ & $\begin{array}{l}\text { Target slump flow } \\
(\mathrm{mm})\end{array}$ & Target air contents $(\%)$ & $\begin{array}{l}\text { Blending ratios of } \\
\text { crushed sand (\%) }\end{array}$ & $\begin{array}{c}\text { Incorporation of fly ash } \\
(\%)\end{array}$ & Evaluation items \\
\hline \multirow[t]{4}{*}{0.25} & \multirow[t]{4}{*}{$600 \pm 100$} & \multirow[t]{4}{*}{$4.5 \pm 1.5$} & \multirow[t]{4}{*}{$0,30,50,70,100$} & \multirow[t]{4}{*}{$0,10,20$} & Slump-flow \\
\hline & & & & & Air content \\
\hline & & & & & $\begin{array}{c}\text { Compressive and } \\
\text { splitting tensile } \\
\text { strength }(3,7, \\
28 \text { days })\end{array}$ \\
\hline & & & & & Statistical analysis \\
\hline
\end{tabular}

Table 2 Physical and chemical properties of binders.

\begin{tabular}{c|c|c|c|c|c|c|c|c|c}
\hline Class & \multirow{2}{*}{$\begin{array}{c}\text { Density } \\
\left(\mathrm{g} / \mathrm{cm}^{3}\right)\end{array}$} & \multirow{2}{*}{$\begin{array}{c}\text { Specific } \\
\text { surface } \\
\end{array}$} & & \multirow{2}{*}{$\begin{array}{c}\text { Soundness } \\
(\%)\end{array}$} & \multicolumn{6}{|c}{ Chemical components (\%) } \\
\cline { 7 - 11 } & & & $\mathrm{CaO}$ & $\mathrm{SiO}_{2}$ & $\mathrm{Al}_{2} \mathrm{O}_{3}$ & $\mathrm{Fe}_{2} \mathrm{O}_{3}$ & $\mathrm{MgO}$ & $\mathrm{SO}_{3}$ \\
\hline \hline Cement & 3.15 & 3,200 & 0.7 & 62.16 & 21.61 & 4.71 & 3.52 & 2.55 & 2.04 \\
\hline Fly-ash & 2.21 & 3,320 & 2.4 & 5.71 & 55.98 & 28.80 & 6.94 & 1.15 & 0.55 \\
\hline
\end{tabular}

Table 3 Physical properties of aggregates.

\begin{tabular}{c|c|c|c|c}
\hline Class of aggregate & Density $\left(\mathrm{g} / \mathrm{cm}^{3}\right)$ & Fineness modulus & Absorption ratio $(\%)$ & Unit weight $\left(\mathrm{t} / \mathrm{m}^{3}\right)$ \\
\hline \hline Gravel & 2.61 & 6.59 & 1.00 & - \\
\hline Sea sand (SS) & 2.59 & 2.80 & 1.14 & 1.39 \\
\hline Crush sand (CS) & 2.59 & 3.98 & 0.69 & 1.51 \\
\hline
\end{tabular}

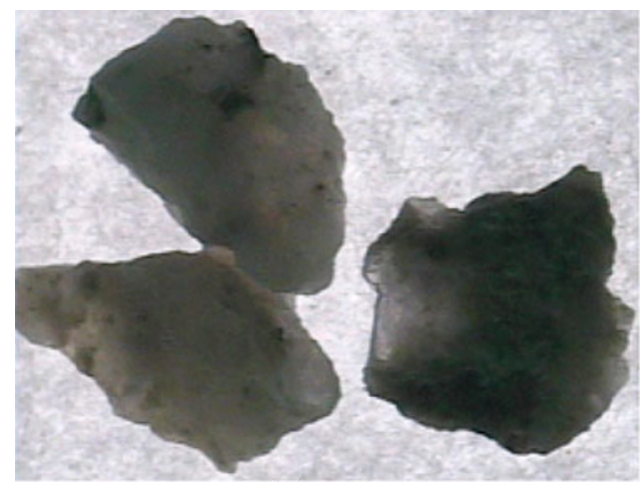

(a) $\mathrm{CS}$

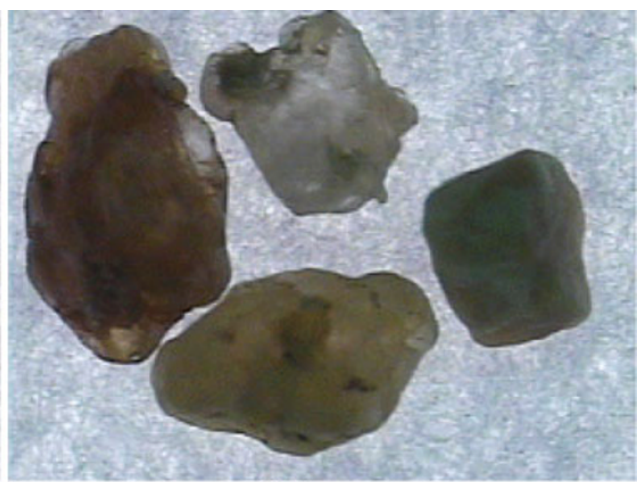

(b) SS

Fig. 1100 times enlarged appearance of fine aggregate.

Figures 1 and 2 show an evaluation method of fine aggregate's shape modulus using an image analysis.

\section{Properties of Mixture Proportion}

\subsection{Particle Size Distribution and Fineness} Modulus

Figure 3 and Table 4 show grading curve and fineness modulus of blended aggregate. In test results, fineness modulus of pure SS was 2.8 and it was suitable for using in concrete. However fineness modulus of pure CS was 3.98 and it was not suitable for concrete aggregate. In case of blended aggregate with CS of mixing ratio of below $50 \%$, its particle size distribution met the standard range even the fineness modulus was relatively high. This is because consumer's demand that they want to use CS with natural sand of low fineness modulus was reflected.

In result of passing amount of $75 \mu \mathrm{m}$ sieve, even pure CS showed a low level of below $1.5 \%$ and it is due to the wet production method. 


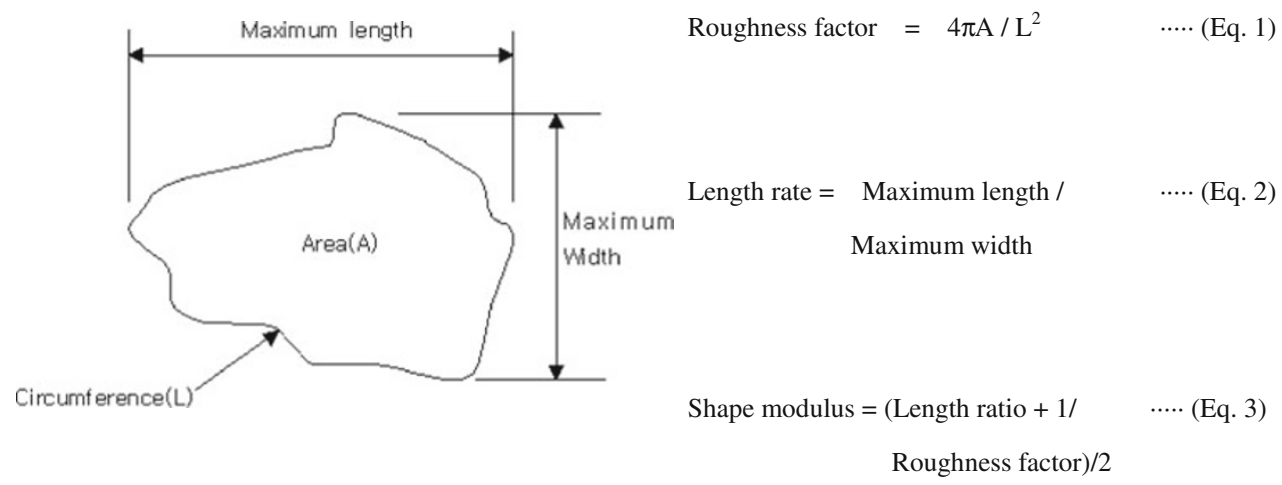

Fig. 2 Shape modulus of fine aggregate.

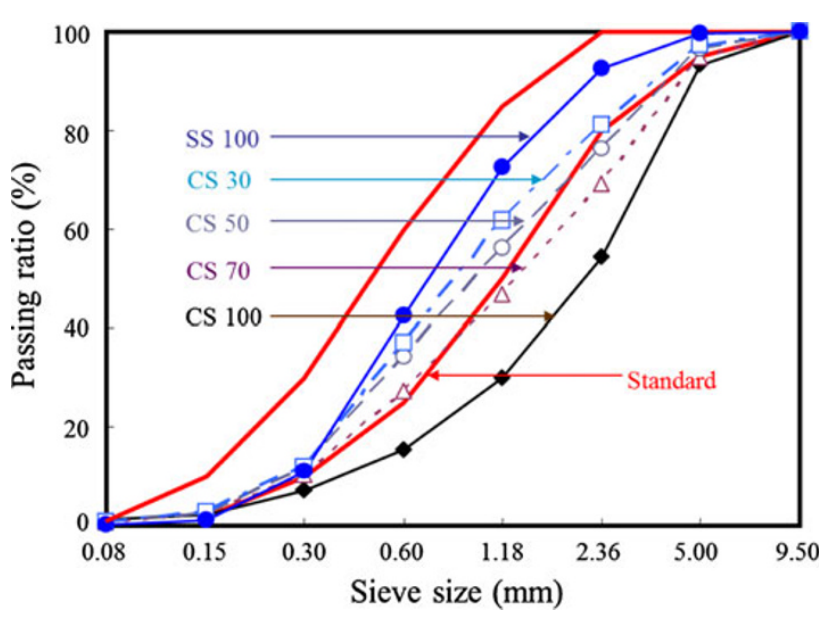

Fig. 3 Grading curve of sand.

\subsection{Bulk Density, Shape Index and Shape Modulus}

This test method using absolute dry density and volume of aggregate is useful for evaluation of overall properties of blended aggregate. However, it has difficulty to evaluate particle shape of aggregate. Therefore, in this study, shape modulus of aggregate was additionally measured and was compared with shape index. Shape modulus measurement is for pure $\mathrm{CS}$ and $\mathrm{SS}$, not for blended aggregate. In shape modulus measurement, 20-50 particles randomly gathered among aggregates in range of $1.2-2.5 \mathrm{~mm}$ sizes were analyzed by using image as shown Fig. 2 and shape modulus was finally calculated by Eqs. (1) to (3).
If the shape of particle is sphere, shape modulus is 1 . And if the shape of particle is more angulate, shape modulus is more than 1. Table 5 shows bulk density, shape index and shape modulus of aggregate.

Bulk density and shape index of blended aggregate were decreased as the blending ratio of CS increased. The shape of CS produced by crusher was more angulate than that of SS. Therefore, if the container was filled with CS, air void became lager. This led low bulk density and shape index of blended aggregate. It also means that if more CS is used in concrete, more paste is needed to meet the target flow-ability and other properties of concrete.

Shape index of pure CS was $52.7 \%$ and was lower than $53 \%$ required by $\mathrm{KS}$.

In blended aggregate, shape index was increased as the blending ratio of SS was increased. Shape index of blended aggregate with SS of mixing ratios of 30,50 and $70 \%$ were relatively $54.1,55.0$ and $56.1 \%$. These values met the KS requirement.

Although mixed aggregate met the $\mathrm{KS}$ requirement in shape index, there were some cases that blended aggregate was unsuitable for concrete aggregate in fineness modulus as shown in Table 4. Therefore, to predict the properties of concrete using CS base on the simple test results of aggregate is difficult.

Shape modulus of pure CS and SS were 1.37 and 1.23, respectively. This result agrees with previous studies have found that SS has more round shape than CS and then

Table 4 Fineness modulus with blending ratios.

\begin{tabular}{c|c|c|c|c|c}
\hline $\begin{array}{c}\text { Blending ratio of CS } \\
(\%)\end{array}$ & 0 (sea sand) & 30 & 50 & 70 & 100 (crush sand) \\
\hline \hline FM & 2.80 & 3.08 & 3.23 & 3.50 & 3.98 \\
\hline
\end{tabular}

Table 5 Unit weight, shape index and shape modulus with blending ratios.

\begin{tabular}{c|c|c|c|c|c}
\hline $\begin{array}{c}\text { Blending ratio of CS } \\
(\%)\end{array}$ & 0 (sea sand) & 30 & 50 & 70 & 100 (crush sand) \\
\hline \hline Unit weight $\left(\mathrm{t} / \mathrm{m}^{3}\right)$ & 1.51 & 1.46 & 1.44 & 1.42 & 1.39 \\
\hline Shape index (\%) & 58.1 & 56.1 & 55.0 & 54.1 & 52.7 \\
\hline Shape modulus & 1.23 & - & - & - & 1.37 \\
\hline
\end{tabular}




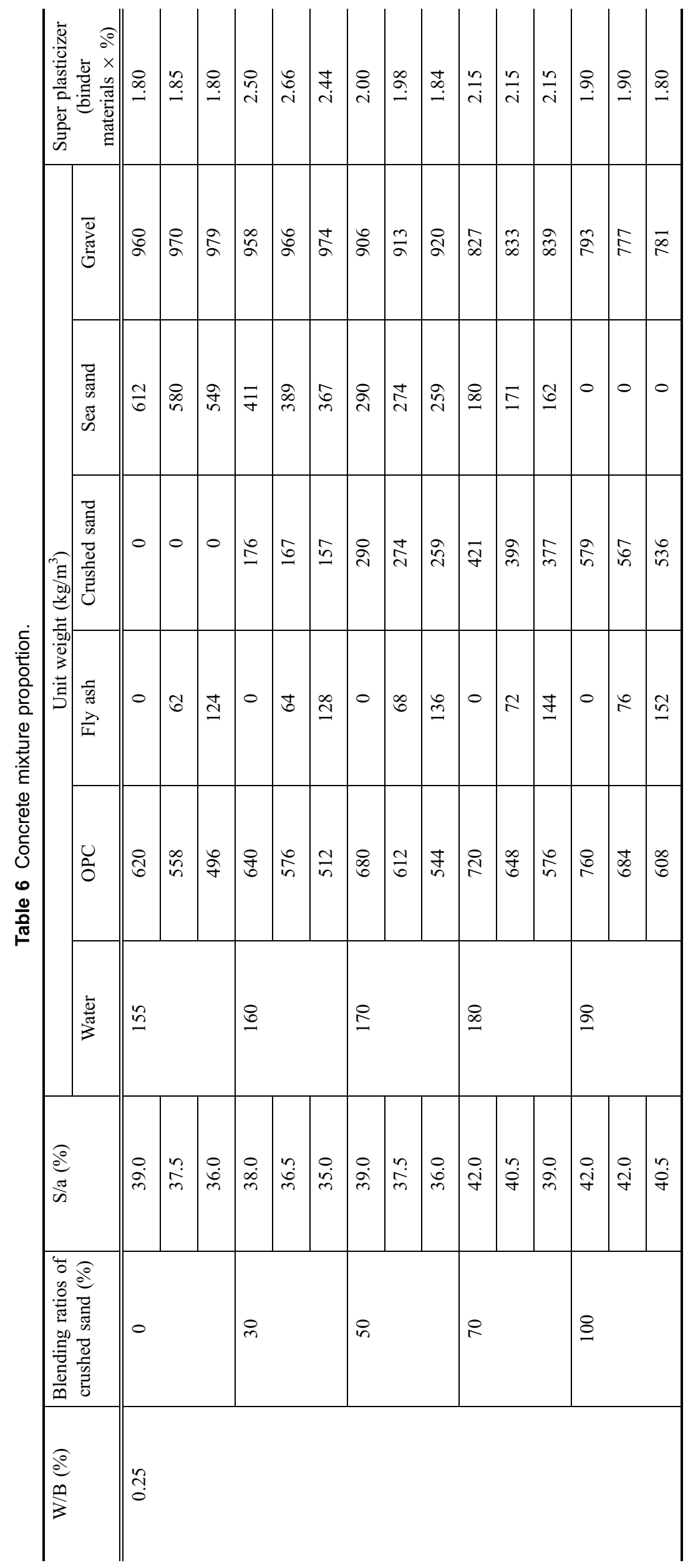


Table 7 Test results of hardened concrete.

\begin{tabular}{|c|c|c|c|c|c|c|c|}
\hline \multirow{2}{*}{$\begin{array}{c}\text { Blending ratios } \\
\text { of crushed sand } \\
(\%)\end{array}$} & \multirow[t]{2}{*}{ S/a (\%) } & \multicolumn{3}{|c|}{ Compressive strength $(\mathrm{MPa})$} & \multicolumn{3}{|c|}{ Splitting tensile strength (MPa) } \\
\hline & & 3 days & 7 days & 28 days & 3 days & 7 days & 28 days \\
\hline \multirow[t]{3}{*}{0} & 39.0 & 47.7 & 50.4 & 63.1 & 3.89 & 4.29 & 5.20 \\
\hline & 37.5 & 42.4 & 47.8 & 62.9 & 3.62 & 3.87 & 4.97 \\
\hline & 36.0 & 35.2 & 41.2 & 65.1 & 3.12 & 4.11 & 5.28 \\
\hline \multirow[t]{3}{*}{30} & 38.0 & 42.1 & 47.7 & 60.6 & 3.13 & 3.62 & 4.90 \\
\hline & 36.5 & 35.5 & 49.4 & 59.9 & 3.17 & 3.38 & 4.89 \\
\hline & 35.0 & 36.5 & 41.2 & 61.0 & 3.76 & 3.86 & 4.44 \\
\hline \multirow[t]{3}{*}{50} & 39.0 & 44.0 & 48.2 & 62.2 & 4.20 & 4.48 & 4.62 \\
\hline & 37.5 & 41.5 & 47.8 & 64.9 & 3.99 & 4.03 & 4.54 \\
\hline & 36.0 & 39.9 & 46.8 & 62.4 & 3.07 & 4.12 & 4.89 \\
\hline \multirow[t]{3}{*}{70} & 42.0 & 43.1 & 54.6 & 64.0 & 3.89 & 4.37 & 4.88 \\
\hline & 40.5 & 39.7 & 48.1 & 63.9 & 3.87 & 4.37 & 4.98 \\
\hline & 39.0 & 38.2 & 48.7 & 65.8 & 3.11 & 3.61 & 5.29 \\
\hline \multirow[t]{3}{*}{100} & 42.0 & 49.6 & 55.6 & 64.7 & 2.81 & 4.10 & 4.28 \\
\hline & 42.0 & 50.0 & 56.1 & 65.8 & 3.94 & 4.20 & 4.92 \\
\hline & 40.5 & 47.4 & 54.5 & 69.9 & 3.86 & 4.27 & 4.80 \\
\hline
\end{tabular}

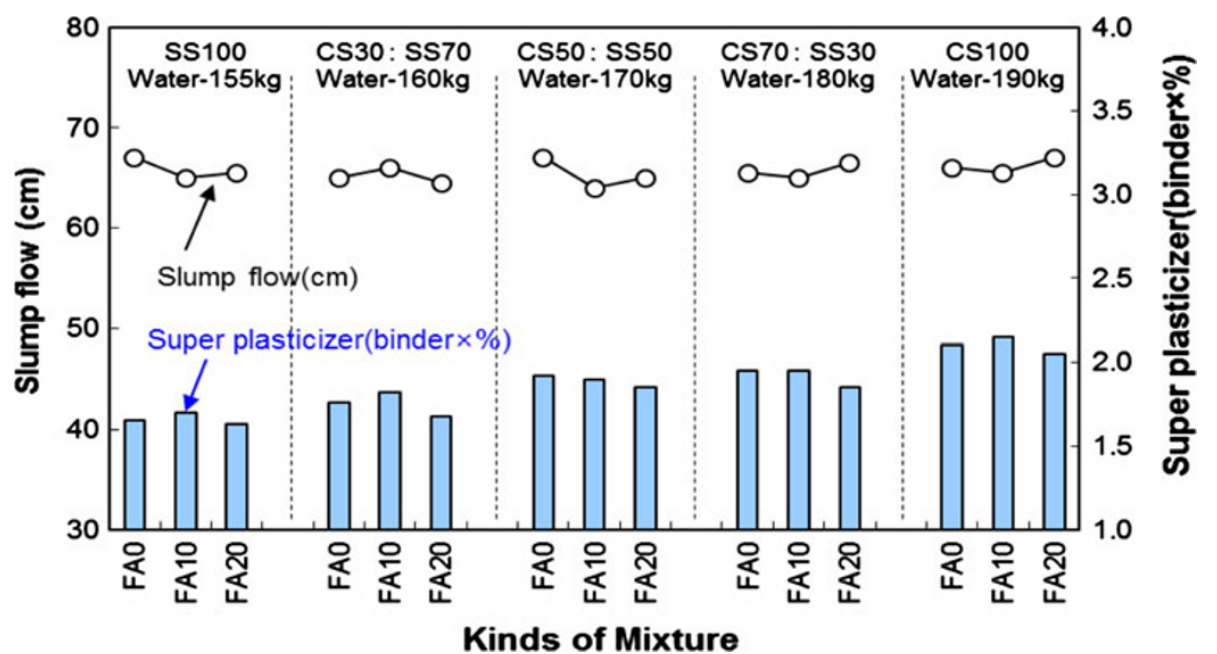

Fig. 4 Slump flow and super plasticizer content in concrete with the blending ratio of CS.

concrete using SS shows good qualities in fresh and hardened concrete properties.

Therefore shape modulus of aggregate is useful item for evaluating the properties of concrete aggregate.

\section{Concrete Mix Property}

The experimental results of high performance concrete using CS are shown in Tables 6 and 7. Figure 4 shows the amount of super plasticizer used in concrete containing CS with different blending ratios.
The super plasticizer was more used as the mixing ratio of $\mathrm{CS}$ was increased. Especially, in concrete using only CS, the super plasticizer of over $2.0 \%$ of total binder by mass was needed, even the unit water content was large. Under the condition of same unit water content, the flow-ability of concrete using CS decreased as the content of FA increased, and its change was little different (Lee et al. 1997; Han and Yoon 1996).

Figure 5 shows the changes of the unit water content and fine aggregate ratio in concrete with the blending ratios of $\mathrm{CS}$. As the blending ratios of CS increased, the unit water content and fine aggregate ratio increased to meet the target flow- 


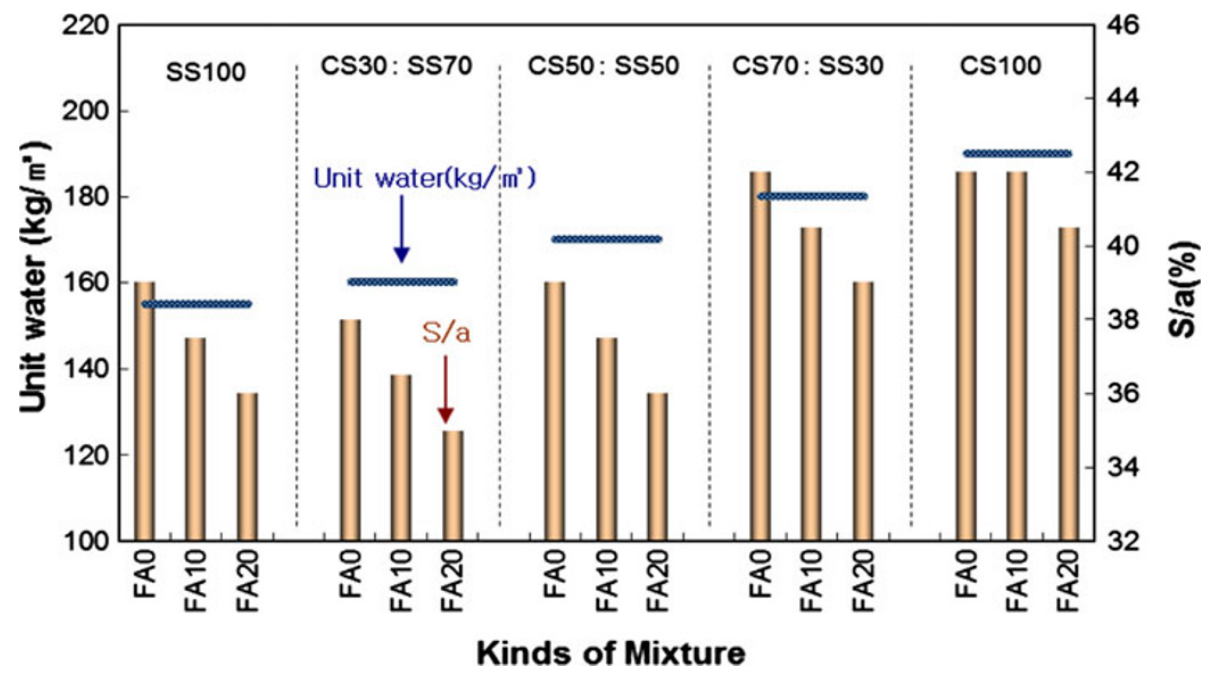

Fig. 5 Unit water content and S/a in concrete with the blending ratio of CS.

Table 8 Test results of correlation analysis by SPSS.

\begin{tabular}{c|c|c|c|c|c|c|c}
\hline & CS (\%) & FA (\%) & S/a (\%) & W & $f_{c k} 3$ & $f_{c k} 7$ & $f_{c k} 28$ \\
\hline \hline CS (\%) & 1 & 0 & 0.731 & 0.986 & 0.509 & 0.714 & 0.573 \\
\hline FA (\%) & & 1 & -0.490 & 0 & -0.509 & -0.448 & 0.324 \\
\hline S/a (\%) & & & 1 & 0.791 & 0.760 & 0.882 & 0.520 \\
\hline $\mathrm{W}$ & & & & 1 & 0.550 & 0.741 & 0.660 \\
\hline$f_{c k} 3$ & & & & & & 0.806 & 0.438 \\
\hline$f_{c k} 7$ & & & & & & & \\
\hline$f_{c k} 28$ & & & & & & & \\
\hline
\end{tabular}

ability. The unit water content of over $180 \mathrm{~kg} / \mathrm{m}^{3}$ and fine aggregate ratio of over $39.0 \%$ were required to meet the slump-flow of 600-700 $\mathrm{mm}$ when CS of blending ratio of over $70 \%$ was used. Korean standard specification for building construction describes that the maximum unit water content is $185 \mathrm{~kg} / \mathrm{m}^{3}$ for the durability of concrete. In this study, the unit water content was needed over $185 \mathrm{~kg} / \mathrm{m}^{3}$ when CS was only used in concrete (Won 2004; Koh 2006).

Therefore, the optimization of the blending ratio of CS has to be proceed to make high performance concrete having high durability, strength and flow-ability when CS is used.

In general, proper amounts of S/a, unit weight and super plasticizer were differently used in the mixture. It was dependent on blending ratios of CS and incorporation ratios of FA.

Meanwhile, at the age of 28 days, compressive strengths of specimens combining less than $50 \%$ of CS were evaluated slightly lower or similar compared to that of a control concrete. For specimens combining 70 and $100 \%$ of CS the values were improved 1.39 and $4.64 \%$, respectively in overall. These strength properties were exactly opposed to grading properties given in 2.3. It was determined that although specimens using CS decreased the fluidity, they even increased the strength (Kim 1997).

Table 8 shows statistical analysis results, using SPSS software, of mutual relation between mixing parameters based on the test results above. In this table, some of the data were omitted to help understanding because the values were exactly symmetrical with others shown in upper right section.

It was shown that CS had a significant level on S/a and unit water content. It was thought because the increase of CS blending ratio in the mixture requested higher S/a and unit water content in order to maintain the target fluidity. However, compressive strength of specimens was shown as a significant level only at the age of 7 days $\left(f_{c k} 7\right)$. It was found that strength properties of concrete using CS at the very early age or after certain time were more affected by strength development properties of binders instead of CS. Meanwhile, the values of FA were in inverse proportion to $f_{c k} 3$ and $f_{c k} 7$ but it was in proportion to $f_{c k} 28$, respectively. It is certainly confirmed that strength development, in a long age, of FA concrete is performed by pozzolanic reaction of that.

\section{Conclusion}

In this study it was investigated the practical use of high performance concrete with various blending ratios of both CS and SS produced in Korea and evaluated the mutual correlation of mixing parameters using SPSS software. It was found that: 
(1) Blended aggregate met the range of optimal fineness modulus for concrete when the bending ratio of CS was below $30 \%$. The shape index of pure CS was $52.7 \%$ and was closed to the specification requirement of $53 \%$.

(2) The super plasticizer was more needed as the blending ratio of CS was increased. Especially, in concrete using only CS, the super plasticizer of over $2.0 \%$ of total binder by mass was needed, even the unit water content was $190 \mathrm{~kg} / \mathrm{m}^{3}$.

(3) The optimization of the blending ratio of CS has to be proceed to make high performance concrete having high durability, strength and flow-ability when CS is used.

(4) At 28 days, compressive strengths of the specimens using blended aggregates combining less than $50 \%$ of CS were evaluated lower or similar strength properties to that of a control concrete, while that of specimens using 70 and $100 \%$ of CS was increased average 1.39 and $4.64 \%$, respectively.

(5) In the experimental test results using SPSS software, it was concluded that strength property of concrete using $\mathrm{CS}$ at the very early age or after certain time was mainly affected by strength development properties of binder instead of CS.

\section{Open Access}

This article is distributed under the terms of the Creative Commons Attribution License which permits any use, distribution, and reproduction in any medium, provided the original author(s) and the source are credited.

\section{References}

Celik, T. (1996). Effects of crushed stone dust on some properties of concrete. Journal of Cement and Concrete Research, 1121-1130.

Chi, I. H., Jung, Y. H., Yum, J. H., Choi, J. M., Lee, S. Y., \& Hong, K. S. (2006). A study on the properties of high flowing concrete with quality variation of crushed sand. Proceedings of the Korea Concrete Institute, 18(1), 81-84 (in Korean).

Han, C. G., \& Yoon, G. W. (1996). An experiment study on properties and the mixing design of crushed sand concrete. Architectural Research, 12(9), 263-269 (in Korean).

Kim, J. K. (1997). The fracture characteristics of crushed limestone sand concrete. Journal of Cement and Concrete Research, 1719-1729.

Kim, J. K., \& Lee, C. S. (1995). A study on the fracture characteristics of crushed sand concrete and river sand concrete. Journal of the Korea Concrete Institute, 7(4), 129-136 (in Korean).

Koh, K. T. (2006). Influence of the type of fine aggregate on concrete properties. Journal of the Korea Concrete Institute, 18(4), 459-467 (in Korean).

Lee, S. B., Jee, N. Y., \& Lee, L. H. (1997). The experimental study on the properties and mixing factor of concrete with crushed stone sand by percentages of VFS replacement. Journal of the Regional Association of Architectural Institute of Korea, 13(2), 219-228 (in Korean).

Park, C. L. (1998). The practical application on the super flowing concrete using manufactured sand. Proceedings of the Korea Concrete Institute, 10(1), 9-14 (in Korean).

Won, Y. G. (2004). A study on physical and particle properties of crushed sand in Korea. Proceedings of the Korea Concrete Institute, 16(1), 352-355 (in Korean). 